
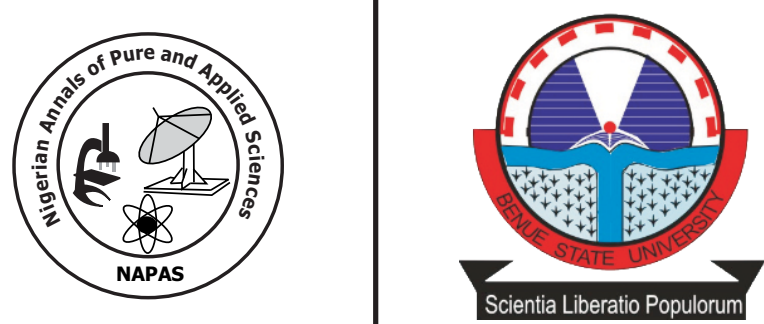

\title{
Nutritional value of Shea Butter (Vitellaria paradoxa) seed Meal (SBSM) as affected by different days of Natural fermentation
}

\author{
Alu, S.E. and Randa, E.A. \\ Department of Animal Science, Faculty of Agriculture, \\ Nasarawa State University, Keffi, \\ P.M.B.135, Shabu-Lafia campus, Nasarawa State, Nigeria. \\ Corresponding author: drsamalu@nsuk.edu.ng
}

\section{Abstract}

A laboratory studies were carried out to investigate the effect of fermentation duration on nutrients and antinutrient composition of shea butter seed meal, SBSM. 500g of the wet unprocessed SBM was cooked for 1 hour after which it was cooled and divided into 5 portions. The first portion was tagged T1 and oven-dried. The remaining 4 were bagged in different air-tight polythene bags and allowed to ferment for 3, 4, 5 and 6 days and each treatment was labeled as T2, T3, T4 and T5, respectively. At the end of the processing, each treatment was replicated and the samples analyzed. Crude protein and ether extract were significantly $(\mathrm{P}<0.05)$ improved as the days of fermentation increased. The values increased from 10.33 and $2.76 \%$ to 15.58 and $4.50 \%$, respectively at day 3 fermentation. However, the values reduced as fermentation entered day 5 and 6 . Fermentation of SBSM for up to day 4 (T5) and 5 (T6) gave the best $(\mathrm{P}<0.05)$ result for crude fibre $(14.37$ and $14.78 \%$ ), whereas fermentation for as early as 3 days gave same result for ash as compared to those of day 4 $(4.48 \%), 5(3.29 \%)$ and $6(3.11 \%)$, respectively. Similarly, fermenting SBSM for up to 4 days gave significantly $(\mathrm{P}<0.05)$ the highest value for gross energy $(3.13 \mathrm{kcal} / \mathrm{kg})$ whereas that of day 5 produced the highest value of NFE (63.51\%) but similar to that of day $2(61.98 \%)$. There was no significant $(\mathrm{P}>0.05)$ variation in the value recorded for DM across the treatments. Consistently, the best $(\mathrm{P}>0.05)$ result obtained for all the minerals evaluated were on the fourth day of fermentation except for days $3(0.06 \%)$ and $6(0.04 \%)$ which were comparable to both the control $(0.09 \%)$ and day $4(0.09 \%)$. Fermenting SBSM for up to day 4 gave the best $(\mathrm{P}>0.05)$ result for potassium $(0.36 \%)$, calcium $(0.18 \%)$ and phosphorus $(0.36 \%)$. However, the treatment did not $(\mathrm{P}<0.05)$ affect the concentration of magnesium. Saponin and phytic acid were significantly $(\mathrm{P}<0.05)$ reduced due to fermentation for 3 to 4 days but were increased $(\mathrm{P}<0.05)$ beyond this duration of fermentation. However, there was no variation $(\mathrm{P}>0.05)$ in the results obtained for tannin $(0.001-0.003 \%)$, oxalate $(0.0010-0.0014 \%)$ and flavonoids $(0.005-0.006 \%)$. The vitamins analyzed namely A, B6 and $\alpha-$ tocopherol were consistently improved $(\mathrm{P}<0.05)$ from the beginning of the time of fermentation up to day 4 but reduced $(\mathrm{P}<0.05)$ beyond this period of fermentation. Monogastric animal farmers can therefore, ferment SBSM for at most 4 days and conveniently feed their animals as a replacement for conventional energy source.

Key words: Shea Butter Seed Meal, Fermentation Duration, Proximate Compositions, Amino Acids and Antinutritional factors 


\section{Introduction}

Shea butter (Vitellaria paradoxa) seed meal is a product that is obtained by chopping the seed and afterwards, either sun dried or cooked before being used as feed for animals or for extraction of fat from the nuts. It is available in large quantities in West Africa. It has similarities in its nutrient compared to wheat feed (NRC, 1994) and other non-conventional feedingstuffs (Alu et al., 2018).

According to Canibe et al. (2006) as cited by Jiankun $\mathrm{Hu}$ et al. (2008), fermentation is widely used to produce healthy foods for people and animals and its interest in its application in animal feeding is increasing due to the total ban on antibiotic growth promoters in the European Union. The authors also noted that the application of fermentation technology in animal feeds can be categorized into that involving fermented raw materials and that involving fermented liquid feed. Raw materials such as soybean and soybean meal (Hong et al., 2004; Cho et al., 2007; Kim et al., 2007), cottonseed meal (Zhang et al., 2006), barley (Canibe and Jensen, 2007), wheat (Canibe and Jensen, 2007) and farm by-products (Oboh and Akindahunsi, 2005; Ramli et al., 2005; Oduguwa et al., 2007) can be fermented, with the aim of eliminating anti-nutritional factors such as gossypol in cottonseed meal (Zhang et al., 2006) and trypsin inhibitor in soybean meal (Hong et al., 2004), improving nutrient digestibility (Cho et al., 2007; Kim et al., 2007) and enriching the quality of protein (Oduguwa et al., 2007). Then the fermentation end products can be incorporated into diets as feed ingredients.

According to Matthew and Alu (2016), shea butter cake is a non-conventional feed resource and it is not consumed by man and presently regarded as waste. It is, unlike other conventional energy sources, which has low human food preference; hence might be a very good substitute; but has some anti-nutritional factors like tannins and saponins that could limit its usage in poultry nutrition.

Most of the conventional feedstuffs for poultry are very expensive and in high demand by human beings and industrial users for consumption and usage respectively. Shea butter cake unlike other conventional energy sources has low human food preference; hence might be a very good substitute; but it has some anti-nutritional factors that could limit its usage in poultry.

The use of non- conventional feed ingredient and the search for other feed resources that are not expensive is therefore necessary (Farinu et al., 2006). Non-conventional feedstuff offers the best alternative into our environment for a reduction in feed cost (Dafwang et al., 2001). In terms of total cost, energy is the main factor influencing diet cost (Afolayan et al., 2009). However, according to Vantsawa (2001), the high cost of maize had led to high cost of poultry feeds. Surprisingly, energy sources (grains) had turned out to be more expensive, thereby increasing the cost of production (Abeke et al., 2003 and Bawa et al., 2003). The aim of this study is therefore; to evaluate the effect of fermentation duration on nutrient and anti-nutrient composition of shea butter seed meal with the view to feeding monogastric animals.

\section{Materials and Methods}

The experiment was carried out in the Biochemistry Laboratory of the Department of Animal Science, Faculty of Agriculture, Nasarawa State University, Keffi, Shabu-Lafia Campus.

\section{Sources of SBSM}

The SBSM was obtained from villages around Shabu in Lafia of Nasarawa State, Nigeria.

\section{Fermentation}

$500 \mathrm{~g}$ of the wet unprocessed SBSM was cooked for 1hour after which it was cooled and divided into 5 portions. The first portion was tagged $\mathrm{T} 1$ and oven-dried. The remaining 4 were bagged in different air-tight polythene bags and allowed to ferment for 3, 4, 5 and 6 days and each treatment was labeled as T2, T3, T4 and T5, respectively. At the end of the processing, each treatment was replicated and samples were taken for analysis.

\section{Biochemical analysis}

Proximate analyses of the samples of milled differently processed SBSM were carried out at the IAR\&T, Moor Plantation, Ibadan, Nigeria, using the procedure outlined by Galyean (2010). Dry matter (\% DM) was calculated as the 100 minus the percent moisture content while the nitrogen free extract (\%NFE) was calculated by difference; using the formula:

$\mathrm{NFE}=100-(\% \mathrm{CP}+\% \mathrm{CF}+\% \mathrm{EE}+\mathrm{Ash}+\%$ Moisture).

\section{Determination of vitamins, minerals and amino acid}

For the determination of vitamins and mineral profile, $0.5 \mathrm{~g}$ of each wet digested samples of Shea butter meal was analyzed by the method described by AOAC (2012). The Technicon Sequential Multi-sample Aminoacid analyzer (TSM)-Model DNA 0209 was used to determine the profile of the aminoacids according to the methods outlined by Speckman et al. (1958). 


\section{Determination of phytochemicals}

Phytic acid determination was done according to the modified method described by Wheeler and Ferrel (1971) and Steward (1974) while trypsin inhibitor activity was determined according to the methods described by Gupta and Deodhar (1975) and Hammerstr and et al. (1981). The methods share the same principles of determining trypsin inhibitors in soybeans products based on the tryptic hydrolysis of the synthetic substrate, benzoyl-DL-argininenitroanilide (BAPA).

The Spectrophotometric method of Brunner (1984) was used for saponin analysis of tannin while oxalate was determined using the methods outlined by Swain (1979). The method of estimation of tannin content in extract by Joslyn (1970) was used for the determination of tannin content in the samples. Finely ground sample $(0.5$ g) was defatted with 5\% ethyl ether for $15 \mathrm{~min}$. The tannin in the defatted sample was then extracted with methanol and the absorbance at 760 nm was measured.

\section{Experimental design}

The experimental design was a Completely Randomized Design and the following statistical model was used:

Yij $=U+T 1+€ i j$, Where $Y i j=$ is the individual observation, $U$ is the Population Mean, $\mathrm{T} 1$ is the Treatment Error and €ijis the Random error.

\section{Statistical analysis}

All the data collected were statistically analyzed using the general linear model of Statistical Analysis System (SAS, 2008).

\section{Results and Discussion \\ Effect of fermentation duration on proximate composition of SBSM}

The result of the effect of fermentation duration on proximate composition of SBSM is presented in Table 1.Crude protein and ether extract were significantly $(\mathrm{P}<0.05)$ improved as the days of fermentation increased. This is noticed as the values increased from 10.33 and $2.76 \%$ to 15.58 and $4.50 \%$, respectively at day 3 of fermentation. However, the values reduced as fermentation entered day 5 and 6 . Fermentation of SBSM for up to day 4 (T5) and 5 (T6) produced the highest $(\mathrm{P}<0.05)$ result for crude fibre $(14.37$ and $14.78 \%$ ) whereas fermentation for as early as 3 days gave same result for ash as compared to those of day 4 (4.48\%), 5 (3.29\%) and 6 (3.11\%), respectively. The values obtained for crude protein $(6.18$ to $15.58 \%)$ in the present study are higher than those earlier (5.56 to $9.38 \%$ ) reported by Matthew and Alu (2016) for shea butter meal and were close to that of maize. A similar trend was recorded for ether extract, crude fibre, NFE and gross energy as earlier reported (Alu, 2016).

Similarly, fermenting SBSM for up to 4 days gave significantly $(\mathrm{P}<0.05)$ the highest value for gross energy $(3.13 \mathrm{kcal} / \mathrm{kg})$ whereas that of day 5 produced the highest value of NFE (63.51\%) but similar to that of day $2(61.98 \%)$. This high value of NFE implies that the test ingredient is rich in carbohydrate (Mcdonald et al. 1995). There was no significant $(\mathrm{P}>0.05)$ variation in the value recorded for DM across the treatments. However, the low level of moisture content is an indication of better keeping quality of the test ingredient as compared to other non-conventional feeding stuffs.

Table 1.Effects of fermentation duration on proximate composition of SBSM

\begin{tabular}{lllllll}
\hline Parameters & T1 & T2 & T3 & T4 & T5 & LOS \\
\hline Crude protein (\%) & $15.23 \pm 0.63^{\mathrm{a}}$ & $10.33 \pm 5.73^{\mathrm{ab}}$ & $15.58 \pm 0.14^{\mathrm{a}}$ & $6.18 \pm 0.41^{\mathrm{b}}$ & $7.44 \pm 1.92^{\mathrm{b}}$ & $*$ \\
Ether extract (\%) & $4.53 \pm 0.16^{\mathrm{a}}$ & $2.76 \pm 1.13^{\mathrm{b}}$ & $4.50 \pm 0.11^{\mathrm{a}}$ & $1.97 \pm 0.14^{\mathrm{b}}$ & $2.41 \pm 0.66^{\mathrm{b}}$ & $*$ \\
Crude fibre (\%) & $6.38 \pm 0.10^{\mathrm{b}}$ & $10.06 \pm 6.13^{\mathrm{ab}}$ & $6.27 \pm 0.13^{\mathrm{b}}$ & $14.37 \pm 1.27^{\mathrm{a}}$ & $14.78 \pm 0.61^{\mathrm{a}}$ & $*$ \\
Ash (\%) & $3.75 \pm 1.10^{\mathrm{a}}$ & $3.50 \pm 0.75^{\mathrm{a}}$ & $4.48 \pm 0.35^{\mathrm{ab}}$ & $3.29 \pm 0.11^{\mathrm{a}}$ & $3.11 \pm 0.25^{\mathrm{a}}$ & $*$ \\
Dry matter (\%) & $90.35 \pm 0.62$ & $88.26 \pm 2.40$ & $90.44 \pm 0.28$ & $89.31 \pm 0.57$ & $88.38 \pm 2.34$ & NS \\
GE (kcal/kg) & $3.32 \pm 0.25^{\mathrm{a}}$ & $1.91 \pm 0.01^{\mathrm{b}}$ & $3.13 \pm 0.04^{\mathrm{a}}$ & $1.96 \pm 0.20^{\mathrm{b}}$ & $1.92 \pm 0.01^{\mathrm{b}}$ & $*$ \\
NFE (\%) & $59.72 \pm 0.31^{\mathrm{b}}$ & $61.98 \pm 0.40^{\mathrm{ab}}$ & $59.57 \pm 1.36^{\mathrm{b}}$ & $63.51 \pm 1.36^{\mathrm{a}}$ & $60.88 \pm 0.77^{\mathrm{b}}$ & $*$
\end{tabular}

$\mathrm{GE}=$ Gross energy, LOS $=$ Level of significance, $\mathrm{a}, \mathrm{b}=$ means on the same row bearing different superscripts differ significantly, ${ }^{*}=$ Significant at $5 \%(\mathrm{P}<0.05), \mathrm{NS}=$ Not significant at $5 \%(\mathrm{P}>0.05)$.

\section{Effect of fermentation duration on mineral concentration of SBSM}

The result of the effect of fermentation duration on mineral concentration of SBSM is presented in Table 2. Consistently, the best $(\mathrm{P}>0.05)$ result obtained for all the minerals evaluated were on the fourth day of fermentation except for days $3(0.06 \%)$ and $6(0.04 \%)$ which were comparable to both the control $(0.09 \%)$ and day $4(0.09 \%)$. Fermenting SBSM from days 1 and 4 gave the best $(\mathrm{P}>0.05)$ results for potassium, calcium and phosphorus. However, the treatment 
Table 2: Effects of fermentation duration on mineral composition of SBSM

\begin{tabular}{lllllll}
\hline Parameters & T1 & T2 & T3 & T4 & T5 & LOS \\
\hline Sodium (\%) & $0.09 \pm 0.01^{\mathrm{ab}}$ & $0.06 \pm 0.05^{\mathrm{ab}}$ & $0.09 \pm 0.00^{\mathrm{a}}$ & $0.03 \pm 0.01^{\mathrm{b}}$ & $0.04 \pm 0.01^{\mathrm{ab}}$ & $*$ \\
Potassium (\%) & $0.36 \pm 0.02^{\mathrm{a}}$ & $0.19 \pm 0.00^{\mathrm{b}}$ & $0.28 \pm 0.12^{\mathrm{ab}}$ & $0.18 \pm 0.01^{\mathrm{b}}$ & $0.20 \pm 0.01^{\mathrm{b}}$ & $*$ \\
Calcium (\%) & $0.18 \pm 0.01^{\mathrm{ab}}$ & $0.16 \pm 0.04^{\mathrm{ab}}$ & $0.18 \pm 0.00^{\mathrm{a}}$ & $0.13 \pm 0.00^{\mathrm{b}}$ & $0.14 \pm 0.01^{\mathrm{ab}}$ & $*$ \\
Phosphorus (\%) & $0.35 \pm 0.02^{\mathrm{ab}}$ & $0.29 \pm 0.04^{\mathrm{ab}}$ & $0.36 \pm 0.00^{\mathrm{a}}$ & $0.22 \pm 0.00^{\mathrm{ab}}$ & $0.21 \pm 0.01^{\mathrm{b}}$ & $*$ \\
Magnesium (\%) & $0.27 \pm 0.02$ & $0.24 \pm 0.04$ & $0.27 \pm 0.01$ & $0.22 \pm 0.00$ & $0.22 \pm 0.01$ & NS \\
\hline
\end{tabular}

LOS $=$ Level of significance, $\mathrm{a}, \mathrm{b}=$ means on the same row bearing different superscripts differ significantly $*=$ Significant at $5 \%(\mathrm{P}<0.05), \mathrm{NS}=$ Not significant at $5 \%(\mathrm{P}>0.05)$.

Table 3: Effects of fermentation duration on phytochemical constituents of SBSM

\begin{tabular}{lllllll}
\hline Parameters & T1 & T2 & T3 & T4 & T5(Day 6) & LOS \\
\hline Tannin (\%) & $0.003 \pm 0.001$ & $0.002 \pm 0.001$ & $0.003 \pm 0.000$ & $0.002 \pm 0.000$ & $0.001 \pm 0.001$ & NS \\
Saponin (\%) & $0.145 \pm 0.002^{\mathrm{b}}$ & $0.132 \pm 0.015^{\mathrm{b}}$ & $0.129 \pm 0.006^{\mathrm{b}}$ & $0.243 \pm 0.006^{\mathrm{a}}$ & $0.254 \pm 0.004^{\mathrm{a}}$ & $*$ \\
Phytate (\%) $^{\mathrm{b}}$ & $0.011 \pm 0.001^{\mathrm{c}}$ & $0.013 \pm 0.001^{\mathrm{abc}}$ & $0.012 \pm 0.001^{\mathrm{bc}}$ & $0.014 \pm 0.001^{\mathrm{ab}}$ & $0.015 \pm 0.001^{\mathrm{a}}$ & $*$ \\
Oxalate (\%) & $0.010 \pm 0.002$ & $0.014 \pm 0.002$ & $0.012 \pm 0.003$ & $0.013 \pm 0.001$ & $0.014 \pm 0.001$ & NS \\
Flavonoids (\%) & $0.006 \pm 0.001$ & $0.005 \pm 0.003$ & $0.006 \pm 0.000$ & $0.006 \pm 0.002$ & $0.006 \pm 0.005$ & NS \\
TIA (TUI/mg) & $5.430 \pm 0.057^{\mathrm{a}}$ & $3.755 \pm 0.001^{\mathrm{ab}}$ & $5.370 \pm 0.057^{\mathrm{a}}$ & $2.460 \pm 0.090^{\mathrm{b}}$ & $2.310 \pm 0.226^{\mathrm{b}}$ & $*$
\end{tabular}

LOS $=$ Level of significance, $a, b, c=$ means on the same row bearing different superscripts differ significantly $*=$ Significant at $5 \%(\mathrm{P}<0.05), \mathrm{NS}=$ Not significant at $5 \%(\mathrm{P}>0.05)$, TIA-Trypsin inhibitor activity.

\section{Effect of fermentation duration on vitamins composition of SBSM}

The vitamins analyzed (Table 4) namely $\mathrm{A}, \mathrm{B}_{6}$ and $\alpha$-tocopherol were consistently improved $(\mathrm{P}<0.05)$ from the beginning of the time of fermentation up to day 4 but reduced $(\mathrm{P}<0.05)$ beyond this period of fermentation. This observation may be as a result of the cooking effect before fermentation of the SBSM which leached out the water soluble vitamins. The activities of microorganisms responsible for the fermentation may have also contributed in decrease in the vitamins concentration as they may have been used up for their own metabolism.

Table 4: Effects of fermentation duration on vitamins composition of SBSM

\begin{tabular}{lllllll}
\hline Parameters & T1 & T2 & T3 & T4 & T5 & $\begin{array}{l}\text { LO } \\
\text { S }\end{array}$ \\
\hline Vitamin A (\%) & $93.07 \pm 0.25^{\mathrm{a}}$ & $67.35 \pm 0.65^{\mathrm{ab}}$ & $92.35 \pm 1.40^{\mathrm{a}}$ & $43.56 \pm 3.29^{\mathrm{b}}$ & $45.53 \pm 3.33^{\mathrm{b}}$ & $*$ \\
Vitamin B $_{6}(\%)$ & $3.39 \pm 0.04^{\mathrm{a}}$ & $2.24 \pm 1.65^{\mathrm{ab}}$ & $3.38 \pm 0.18^{\mathrm{a}}$ & $1.15 \pm 0.17^{\mathrm{b}}$ & $1.26 \pm 0.13^{\mathrm{b}}$ & $*$ \\
Vitamin E (\%) & $24.44 \pm 0.10^{\mathrm{a}}$ & $13.09 \pm 6.30^{\mathrm{ab}}$ & $24.39 \pm 0.39^{\mathrm{a}}$ & $1.68 \pm 0.34^{\mathrm{b}}$ & $1.85 \pm 0.10^{\mathrm{b}}$ & $*$ \\
\hline
\end{tabular}

$\mathrm{LOS}=$ Level of significance, $\mathrm{a}, \mathrm{b}=$ means on the same row bearing different superscripts differ significantly $*=$ Significant at $5 \%(\mathrm{P}<0.05)$.

\section{Effect of fermentation duration on amino acid composition of SBSM}

The effect of fermentation duration on some amino acid composition of SBSM is presented in Table 5. As in the case of vitamins, all the amino acids analyzed; lysine, methionine and tryptophan were also improved $(\mathrm{P}<0.05)$ from the beginning of the fermentation to day 4 but reduced $(\mathrm{P}<0.05)$ as the days of fermentation proceeded beyond day 4 .

Table 5: Effects of fermentation duration on amino acid composition of SBSM

\begin{tabular}{lllllll}
\hline Parameters & T1 & T2 & T3 & T4 & T5 & LOS \\
\hline Lysine (\%) & $1.87 \pm 0.04^{\mathrm{a}}$ & $1.08 \pm 0.91^{\mathrm{ab}}$ & $1.84 \pm 0.07^{\mathrm{a}}$ & $0.42 \pm 0.01^{\mathrm{b}}$ & $0.49 \pm 0.07^{\mathrm{b}}$ & $*$ \\
Methionine (\%) & $0.67 \pm 0.07^{\mathrm{a}}$ & $0.32 \pm 0.27^{\mathrm{b}}$ & $0.65 \pm 0.04^{\mathrm{a}}$ & $0.10 \pm 0.02^{\mathrm{b}}$ & $0.18 \pm 0.04^{\mathrm{b}}$ & $*$ \\
Tryptophan (\%) & $0.61 \pm 0.06^{\mathrm{a}}$ & $0.29 \pm 0.30^{\mathrm{ab}}$ & $0.57 \pm 0.06^{\mathrm{a}}$ & $0.05 \pm 0.01^{\mathrm{b}}$ & $0.15 \pm 0.05^{\mathrm{b}}$ & $*$ \\
\hline
\end{tabular}

LOS $=$ Level of significance, $a, b=$ means on the same row bearing different superscripts differ significantly, $*=$ Significant at $5 \%(\mathrm{P}<0.05)$. 


\section{Conclusion and Recommendation}

Monogastric animal farmers can ferment SBSM for at most 4 days and conveniently feed their animals as a replacement for conventional energy source without affecting the growth performance of the animals. Further research especially in feeding trial is however advocated to confirm the suitability of this ingredient in question.

\section{References}

Abeke, F. O., Ogundipe, S. O., Sekoni, A. A., Dafwang I. I and Oladele, S. B. (2003).Effect of duration of cooking of LabLab Beans on organ weight and blood parameters of pullets chicks. Proc. of the 28th annual NSAP conference, Ibadan, 28:240-242.

Achi, O.K., Anokwuru, I.C. and Ogbo, F.C. (2007).Microbiological and Chemical Changes during Fermentation of Crabs for ogiri-nsiko Production. American Journal of Food Technology, 2: 301-306.

Adebayo,S.F. (2014). Effect of soaking time on the proximate, mineral compositions andanti-nutritional factors of Lima Bean ISSN 2224-6088(Paper) ISSN22250557(Online) Vol.27.

Afolayan, M., Dafwang I. I., Omage J.J and Afolayan M.O. (2009). Performance of broiler finisherfed on high energy diet and low energy diet during the wet, hot and cold seasons. Proc. of the 28th annual NSAP conference Ibadan, 28:240-242.

Alu, S.E. (2016). Effect of hydrothermal processing duration on nutrients and antinutrients compositions of flamboyant seeds. NSUK journal of science \& technology, vol. 6: no. 2. 2016. Pp. 130 -133 ISSN: 15975527.

Alu, S.E., Randa1, E.A., Lawee, Y.A. and Baba, M.K. (2018b). Nutritional quality of shea butter seed (Vitellaria Paradoxa) meal cooked at different durations. Journal of Agriculture and Agricultural Technology 9(1): 15-26, 2018.

AOAC (2012).Official methods of Analysis of the Association of Analytical Chemists (AOAC) International ( $19^{\text {th }}$ Edition) Washington D.C.

Bawa, G.S. (2003). Effect of cooking time on the level of anti-nutritional factors and the nutritive value of lablab seeds for pigs Ph.D. Thesis, A.B.U. Zaria.

Brunner, J. H. (1984). Direct Spectrophotometer determination of Saponin. Anal. Chem. 34:1314 - 1326.

Canibe, N. and Jensen, B. B. (2007).Fermented liquid feed and fermented grain to pigletseffect on gastrointestinal ecology and growth performance. Livest. Sci. 108:232235.

Canibe, N., Virtanen, E. and Jensen, B. B. (2006). Microbial and nutritional characteristics of pig liquid feed during fermentation. Anim. Feed. Sci. Technol. 134:108-123.

Cho, J. H., Min, B. J., Chen, Y. J., Yoo, J. S. Wang, Q., Kim, J. D. and Kim, I. H. (2007). Evaluation of FSP (fermented soy protein) to replace soybean meal in weaned pigs: growth performance, blood urea nitrogen and total protein concentrations in serum and nutrient digestibility. Asian-Aust. J. Anim. Sci. 20:1874-1879.

Dafwang, I., Ikani, E.J., Chikwendu, D.O., Adesheinwa, A.O.K., Annate, A.I and Iwuayanwu, I.E.J. (2001).An assessment of adoption of non-conventional feedstuffs by poultry and rabbit research. (3):3-5. Department of Animal and Food Sciences, Texas Tech University, Lubbock. Pp. 13 38.

Farinu, G.O.,Togun, V.A., Ojebiyi, O.O., Akinlade, J.A and Popoola, O.B. (2006). Performance of male rabbits fed two levels of wild sunflower (Tithoniadiversifolia) forage meal. In: proceeding 31st Annual Conference, Nigerian society for Animal production 12th -15th march 2006, Kano state P. 243.

Galyean, M. L. (2010). Laboratory procedures in animal nutrition research.

Gupta, A. K. and Deodhar, A. D. (1975).Variation in Trypsin inhibitor activity in soybean (Glycine max).Indian J. Nut. Diet, 12: 8184.

Hammerstrand, G. E., Black, L. T. and Glover, J. D. (1981). Trypsin inhibitor activity in soybean products modification of standard analytical procedure. Cereal Chem., 58: 42 45.

Hong, K. I., Lee, C. H. and Kim, S. W. (2004). AspergillusoryzaeGB-107 fermentation improves nutritional quality of food soybeans and soybean meal. J. Med. Food 7:430-436.

Jiankun, H., Wenqing, Lu.,Chunlin, W., Ronghua, Z. and Jiayun, Q. (2008). Characteristics of solid-state fermented feed and its effects on performance and nutrient digestibility in growing-finishing pigs. Asian-Aust. J. Anim. Sci. Vol. 21, No. 11: 1635 - 1641 November 2008.

Kim, Y. G., Lohakare, J. D., Yun, J. H., Heo, S. and Chae, B. J. (2007).Effect of feeding levels of 
microbial fermented soy protein on the growth performance, nutrient digestibility and intestinal morphology in weaned piglets. Asian-Aust. J. Anim. Sci. 20:399404.

Matthew, U.D. and Alu, S.E. (2016).Effect of different processing methods of Shea butter (Vitellaria paradoxa) cake on serum biochemistry of broiler finisher chickens. Proceedings of the $30^{\text {th }}$ Annual National Conference of the Farm Management Association of Nigeria (University of Abuja 2016) $28^{\text {th }}$ November.

McDonald, P., Edwards, R.A., and Greenhalgh, J.F.D. (1995).Animal nutrition. Fifth edition. Longman Publ. Pp. 221-235.

Oboh, G. and Akindahunsi, A. A. (2005). Nutritional and toxicological evaluation of Saccharomyces cerevisae fermented cassava flour. J. Food Compos. Anal. 18:731-738.

Oduguwa, O. O., Edema, M. O. and Ayeni, A. O. ( 2007 ). Physicochemical and microbiological analyses of fermented corn cob, rice bran and cowpea husk for use in composite rabbit feed. Bioresourse Technol. 99:1816-1820.

Ramli, M. N., Imura, Y., Takayama, K. and Nakanishi, Y. (2005).Bioconversion of sugarcane bagasse with Japanese Koji by solid-state fermentation and its effects on nutritive value and preference in goats.
Asian-Aust. J. Anim. Sci. 18:1279-1284.

SAS (2008). User's Guide Statistics version 6th edition, SAS inst. Inc, cary, North Carolina, U.S.A.

Speckman, D.H., Stein, E.H. and Moore, S. (1958).Automatic recoding apparatus for use in the chromatography of Amino Acids. Association of Analytical Chemists, 30:1190-1191.

Steel, R. G. D. and Torrie, J. A. (1980).Principles and Procedures of statistics. A biometrical Approach. $2^{\text {nd }}$ edition, New York, McGrew Hill Book Co. Inc. 633 p.

Steward, E., (1974).Chemical analysis of ecology material. Blackwell Scientific, Oxford, pp: 298-312.

Swain, T. (1979). Tannins and Lignins. In: Rosenthal, G.A and Janzen, D.H (Eds.) Herbivores: their interaction with plant metabolites. Academic press. New York.

Vantsawa, P. A. (2001). Replacement value of local maize offal (dusa) for maize in broiler diets. Nig. J. Biotech. 12(1): 25-28.

Wheeler, E. L. and Ferrel, R. E. (1971).A method for phytic acid determination in wheat and wheat fractions. Cereal Chem., 48: 312-320.

Zhang, W., Xu, Z. Sun, J. and Yang, X. (2006). A study on the reduction of gossypol levels by mixed culture solid substrate fermentation of cottonseed meal. Asian-Aust. J. Anim. Sci. 19:1314-1321. 